UDC $616.12(008.331)$

DOI: 10.21668/health.risk/2021.1.10.eng

Research article

\title{
HYPERTENSION AMONG COAL MINING WORKERS ASSOCIATED WITH PARENTAL HYPERTENSION IN INDONESIA
}

\section{Kurnia Ardiansyah Akbar}

Faculty of Public Health, Jember University, Jl. Kalimantan No. 42, Krajan Timur, Sumbersari, Kec. Sumbersari, Jember Regency, East Java, 68121, Indonesia

Hypertension is a chronic disease with its prevalence increasing from 2013 to 2018 among population in Indonesia. In 2013 the prevalence of hypertension was 25.8\%, and in 2018 it increased to $34.1 \%$. Therefore, to control hypertension, it is necessary to involve all related parties, doctors and health professionals from various fields of hypertension specialization, government, the private sector, and the public.

Business is a private party that has the authority to participate in the prevention of hypertension in Indonesia. Coal mining sector traditionally creates a lot of workplaces in the country. This study aimed to look at the influence exerted by hypertension in parents' case history on risks of incidence with hypertension among coal mining workers.

This study is a cross-sectional one with two variables, namely hypertension in parents' case histories and hypertension among coal mining workers performed on a sampling including 360 coal mining workers. The results showed that if a father had hypertension in his case history the risk of incidence with hypertension among coal mining workers was 3.143 times higher because OR $=3.143 ; 95 \%$ CI $(1.568<$ OR $<6.229)$, while if a mother had hypertension in her case history the risk of incidence with hypertension among coal mining workers was 6.519 times higher because OR $=6.519 ; 95 \%$ CI $(3,267<O R<13,008)$ and if both parents have hypertension in their case history, the risk of incidence with hypertension among coal mine workers was 6.061 times higher because $\mathrm{OR}=6.061 ; 95 \% \mathrm{CI}(2,910<\mathrm{OR}<12,625)$. The obtained results are enough to prove that hereditary or genetic factors play their role in elevated risks of hypertension in coal mining workers.

Key words: workers, coal mining, coal mining workers, hypertension, risks of hypertension, parental hypertension, hypertension in workers, hypertension in coal mining workers, hypertension in Indonesia.

Hypertension is a chronic disease that becomes apparent via an increase in systolic blood pressure when it exceeds $140 \mathrm{mmHg}$ and diastolic blood pressure being more than $90 \mathrm{mmHg}$ if two measurements are taken in five-minute intervals in a state of sufficient rest and calm [1-3]. As per data obtained by Riskesdas in 2018, hypertension prevalence among Indonesia's population grew from 2013 to 2018. The highest hypertension prevalence was detected in the South Kalimantan $(44.1 \%)$, and the lowest, in Papua $(22.2 \%)$. Hypertension occurs among people aged 31-44 (31.6\%), 45-54 (45.3\%), and 55-64 (55.2\%). In 2013 the prevalence of hypertension was $25.8 \%$, and in 2018 it increased to $34.1 \%$ [4]. Increased blood pressure over a long period can damage the kidneys, brain (causing stroke), and the heart if the hypertension event is not detected early and not properly treated. The number of hypertensive patients with uncontrolled blood pressure is increasing continuously $[5,6]$.

Therefore, the participation of all related parties, both medical doctors from various fields of specialization in hypertension, government, private sector, and society, is needed to control hypertension [7].

One of the private parties that should participate in the prevention of hypertension in Indonesia is business. Coal mining is a sector in economy with a large workforce and growing up every year. Coal mining is laborintensive and capital-intensive economic activity in Indonesia [8]. A coal company's distinctive feature is the number of dwellings in a mining area for workers or what is commonly called a mess. The mess is equipped with all

(C) Akbar Ardiansyah Kurnia, 2021

Akbar Ardiansyah Kurnia - Master of Occupational Health and Safety, Assistant Professor at Faculty of Public Health (e-mail: ardiansyah_akbar@unej.ac.id; tel.: +62-85746757111; ORCID: http://orcid.org/0000-0001-6265-3064). 
adequate facilities starting from a residence, cafeteria, sports venue, places of worship, etc. All adequate facilities were built because most workers have to live in a mining area for $2-5$ weeks before they get a day off $[9,10]$.

The mining work system, which requires employees to live in a mining mess, results in all worker activities being carried out in one area, including work, rest, eating, and sports. The risk of workers experiencing hypertension will occur if their lifestyle, including work patterns, rest, eating, and exercise, is not healthy. It will even be exacerbated in case workers' parents have hypertension in their case history. Research on general population groups in Sri Lanka shows that the prevalence of hypertension increases to $29.3 \%$ if parents have the disease in their case history [11].

This research goal was to examine influence exerted by hypertension in parents' case history on risks of incidence with hypertension among coal mining workers.

Data and methods. This study was a cross-sectional one with two variables, namely hypertension in parents' case history and hypertension among coal mining workers. The data used are primary data obtained via conducting interviews with questionnaires and measuring respondents' blood pressure. Data on hypertension in parents' case history were obtained using a questionnaire filled in by respondents, and data on hypertension among coal mining workers were obtained via direct measuring respondents' blood pressure using a calibrated mercury sphygmomanometer. Hypertension examination was carried out on a respondent's arm by professional physical therapists at a local health clinic [12].

The hypertension measurement results were then classified based on the hypertension classification, referring to JNC VII $2003[12,13]$.

Blood pressure examination is included into a General Medical Check-Up in the framework of annual/periodic health checks on workers following the Regulation of the Minister of Manpower and Transmigration of the Republic of Indonesia No. Per.02 / MEN / 1980 concerning workforce health checks stipulated in the implementation of work safety.
Table 1

Classification of Blood Pressure for Adults

\begin{tabular}{|l|c|c|c|}
\hline \multicolumn{1}{|c|}{ Category } & $\begin{array}{c}\text { Systolic } / \\
\text { SBP } \\
(\mathrm{mmHg})\end{array}$ & & $\begin{array}{c}\text { Diastolic } / \\
\text { DBP } \\
(\mathrm{mmHg})\end{array}$ \\
\hline Normal & $<120$ & And & $<80$ \\
\hline Prehypertention & $120-139$ & Or & $80-89$ \\
\hline Hypertention & & & \\
\hline Stage 1 & $140-159$ & Or & $90-99$ \\
\hline Stage 2 & $>160$ & Or & $>100$ \\
\hline
\end{tabular}

N o t e : Adapted From JNC VII, 2003.

In this study, respondents were coal mine workers in Kalimantan, Indonesia, with a sample size of 360 coal mine workers. The respondents' characteristics included the following: they were all males, their working experience was longer than one year, and they were all working at a mining site. These criteria aim to control for research bias.

Respondents were selected using a sampling technique, namely cluster random sampling. The data were processed by bivariate analysis using a non-parametric test.

Results and discussion. The obtained results are shown in Tables 2-4.

Table 2 shows that 40 respondents out of 360 coal mining workers had hypertension when they were examined and 320 didn't have it. Based on questioning, we detected that 72 people's fathers had hypertension in their case history, while fathers of 288 others did not.

Based on data given in Table 2 we can conclude that there is a relationship between paternal hypertension and coal mining worker hypertension with a p-value of $0.001<\alpha=0.05$. The risk of incidence with hypertension among coal mining workers if a father has a history of hypertension is 3.143 times higher because $\mathrm{OR}=3.143 ; 95 \% \mathrm{CI}(1.568<\mathrm{OR}<6.229)$.

Table 3 shows that 320 respondents out of 360 coal mining workers, did not have hypertension when being checked, while 40 respondents had hypertension when they were examined. Based on questioning, we detected that 78 people's mothers had hypertension in their case history, while mothers of 282 others did not have it. 
Table 2

Hypertension in father's case history influencing risk of hypertension among coal mining worker

\begin{tabular}{|c|c|c|c|c|c|c|}
\hline & \multicolumn{2}{|c|}{ Father's case history } & \multirow{2}{*}{ Total } & \multirow{2}{*}{ p-value } & \multirow{2}{*}{ OR } \\
\hline & & Not-Hypertension & Hypertension & & & \\
\hline \multirow{2}{*}{$\begin{array}{l}\text { Coal mining workers } \\
\text { Hypertension }\end{array}$} & Not-Hypertension & 264 & 56 & 320 & \multirow{2}{*}{0.001} & \multirow{2}{*}{3.143} \\
\hline & Hypertension & 24 & 16 & 40 & & \\
\hline \multicolumn{2}{|l|}{ Total } & 288 & 72 & 360 & & \\
\hline
\end{tabular}

Source: Primary Data.

Table 3

Hypertension in mother's case history influencing risk of hypertension among coal mining worker

\begin{tabular}{|c|c|c|c|c|c|c|}
\hline & \multicolumn{2}{|c|}{ Mother's case history } & \multirow{2}{*}{ Total } & \multirow{2}{*}{$\mathrm{p}$-value } & \multirow{2}{*}{ OR } \\
\hline & & Not-Hypertension & Hypertension & & & \\
\hline \multirow{2}{*}{$\begin{array}{l}\text { Coal mining workers } \\
\text { Hypertension }\end{array}$} & Not-Hypertension & 265 & 55 & 320 & \multirow[b]{2}{*}{0.000} & \multirow[b]{2}{*}{6.519} \\
\hline & Hypertension & 17 & 23 & 40 & & \\
\hline \multicolumn{2}{|l|}{ Total } & 282 & 78 & 360 & & \\
\hline
\end{tabular}

Source: Primary Data.

Table 4

Hypertension in parents' case history influencing risk of hypertension among coal mining worker

\begin{tabular}{|c|c|c|c|c|c|c|}
\hline & \multicolumn{2}{|c|}{ Parents' case history } & \multirow{2}{*}{ Total } & \multirow{2}{*}{ p-value } & \multirow{2}{*}{ OR } \\
\hline & & Not-Hypertension & Hypertension & & & \\
\hline \multirow{2}{*}{$\begin{array}{l}\text { Coal mining workers } \\
\text { Hypertension }\end{array}$} & Not-Hypertension & 223 & 97 & 320 & \multirow[b]{2}{*}{0.000} & \multirow[b]{2}{*}{6.061} \\
\hline & Hypertension & 11 & 29 & 40 & & \\
\hline \multicolumn{2}{|l|}{ Total } & 234 & 126 & 360 & & \\
\hline
\end{tabular}

Source: Primary Data.

Based on data given in Table 3 we can conclude that there is a relationship between a mother having hypertension in her case history and hypertension in a coal mining worker with a p-value of $0.000<\alpha=0.05$. The risk of incidence with hypertension among coal mining workers if a mother has a history of hypertension is 6,519 times higher because $\mathrm{OR}=6,519$; $95 \%$ CI $(3.267<$ OR $<13.008)$.

Table 4 shows that 320 respondents out of 360 coal mining workers, did not have hypertension when being checked, while 40 respondents had hypertension when they were examined. Based on questioning, we detected there were 126 people whose parent, either mother or father, or both of them, had hypertension in his or her (or their) case history whereas parents of the remaining 234 workers did not have it.

Based on data given in Table 4 we can conclude that there is a relationship between hypertension in parents' case history and hyper- tension among coal mining workers with a $\mathrm{p}$ value of $0.000<\alpha=0.05$. The risk of incidence with hypertension among coal mining workers if parents have a history of hypertension is 6,061 higher times because OR $=6,061 ; 95 \%$ CI $(2,910<\mathrm{OR}<12,625)$.

Based on the results obtained via the above research, three main points can be discussed, including influence exerted by paternal hypertension on risk of incidence with hypertension among coal mining workers, by hypertension in father's case history, and hypertension in mothers' case histories as well.

This study shows that the number of hypertension cases is higher among elderly (126 people) than among coal mining workers (40 people), mining workers aged from 18 years to 56 years. This study is in line with previous studies, stating that parents have a high incidence rate of hypertension, especially at the age exceeding 60 years, with a prevalence rate 
being from $60 \%$ to $80 \%[14,15]$. In another study performed in Sao Paulo, it was found that prevalence of hypertension among elderly groups was $70 \%$ of the total population [16]. Research in China also shows that hypertension is found in $53 \%$ of the elderly population [17].

The results showed a relationship between hypertension in a father's, mother's (and parents') case history and incidence with hypertension among coal mining workers. The relationship between hypertension in a father's and mother's case history shows that genetic hypertension can be inherited from either father or mother or even from both parents. According to research that has been done if both parents suffer from hypertension, about $45 \%$ will be passed down to the offspring, and if one parent is suffering from hypertension, about $30 \%$ will be passed down to the offspring $[18,19]$.

In this study, the odds ratio (OR) value for each relationship between variables was obtained. OR $=3.143$ obtained for hypertension in a father's case history shows that if a father has hypertension in his case history, risk of incidence with hypertension among coal mine workers is 3.143 times higher. OR obtained for hypertension in a mother's case history is equal to 6.519 . This means that if a mother hypertensionin her case history, the risk of hypertension among coal mining workers is 6.519 times higher. OR obtained for hypertension in parents' case histories is equal to 6.016. It means that if parents have hypertension in their case history, the risk of hypertension among coal mining workers is 6.061 times higher.

The above research follows the results obtained in previous studies. This study aims to determine the prevalence of hypertension and the determinants of hypertension among elderly people. This research is a quantitative study with a cross-sectional study design in the elderly group. Based on the study results, it was found that a hypertension in family case history is a risk factor causing occurrence of hypertension. The risk of developing hypertension for someone who has hypertension in family case histories is 3.216 times higher than for those whose parents do not have hypertension in their case history [20].

Previous research states that someone whose parents have hypertension in their case history runs higher risk of suffering from hypertension. This possibility occurs because someone whose parents suffer from hypertension, will inherit genes that interact with the environment and cause an increase in blood pressure. Genetic factors result in risks of developing hypertension, as evidenced by a phenomenon that hypertension is more common in monozygous twins (one egg) than in heterozygous (different egg cells). If someone who has a genetic trait of primary (essential) hypertension is then left without therapeutic intervention early on, then exposure to environmental factors will cause hypertension to develop, and at an age of 30-50 years, signs and symptoms will appear [21, 22].

The risk of hypertension, which is related to parental genetics based on previous analysis, is exacerbated by working conditions existing at coal mines. This study focuses on the risk of hypertension among coal mining workers due to exposure to the working environment they have to face at their workplaces and the unhealthy behavior patterns they tend to pursue.

The working environment at coal mines in Indonesia creates occupational risks for workers via physical environmental hazards, namely heat and noise, chemical, environmental hazards, namely coal dust, and psychological dangers. Influence exerted by environmental hazard risks plays a significant role in high prevalence of hypertension among mining workers in Indonesia.

Coal mining environment in Indonesia tends to be dry and hot because it is located along the equator and in tropical climate areas, resulting in increased heat exposure for workers. Heat exposure received by workers is direct exposure to sunlight because Indonesian coal mines are open-pit ones.

Workers are exposed to heat from the sun throughout the year while doing their work. The average temperature in mining areas in Indonesian Kalimantan throughout the year is 
$27.6^{\circ} \mathrm{C}$ or $81.68^{\circ} \mathrm{F}$, with the lowest recorded temperature being $19.1{ }^{\circ} \mathrm{C}$ or $66.38^{\circ} \mathrm{F}$, and the highest temperature is $38^{\circ} \mathrm{C}$ or $100.4^{\circ} \mathrm{F}$ [23]. The temperature distribution indicates that the risk of heat exposure received by coal mining workers is very high compared to normal work climate accepted by general humans.

Exposure to heat while working increases the risk of hypertension for coal mine workers. Exposure to heat while working affects body's internal temperature, which then gradually affects the cardiovascular system. Worker's body exposed to heat automatically tries to adapt to temperatures existing in a working environment by increasing blood flow to the heatexposed skin to control body temperature. This increased blood flow to the skin is accomplished via increased blood flow from the heart. The mechanism of increasing the pump for blood flow from the heart causes the detected blood pressure to increase when measurements are taken.

These results are consistent with previous experimental laboratory studies performed on mice revealing that heat exposure will increase mice's systolic and diastolic blood pressure. Increased blood pressure was detected starting at the moment when mice were exposed to $27^{\circ} \mathrm{C}$ or $80.6^{\circ} \mathrm{F}$ and above [24].

Continuous heat exposure causes a worker's body to adapt significantly. Adaptation in miners' bodies is accomplished via the cardiovascular system that always works above standard, and it can cause hypertension in coal mining workers in Indonesia.

The high risk of hypertension due to heat exposure can be remedied with well-planned prevention. One of them is implementing restrictions on working hours when the ambient temperature is recorded to exceed $27^{\circ} \mathrm{C}$ or $80.6^{\circ} \mathrm{F}$. This temperature becomes a limit because research shows that an increase in blood pressure occurs at that temperature. Limitation imposed on working hours aims to reduce heat exposure experienced by coal mine workers, especially in summer.

Exposure to noise hazards also exacerbates the risk of developing hypertension in coal mining workers in Indonesia. Noise in coal mining comes from heavy equipment, conveyors, subsoil blasting, and coal dredging. Mining workers are exposed to noise during a working shift which is equal to eight hours in Indonesia.

Based on CDC data, it is known that coal mine workers are exposed to noise hazards above $90 \mathrm{dBA}$ at their workplaces [25]. In Indonesia, the noise limit at a workplace for a 8-hour work shift has been stipulated in the Regulation of the Minister of Manpower of the Republic of Indonesia Number 5 of 2018 concerning Occupational Safety and Health. According to it noise in a work environment should not exceed $85 \mathrm{dBA}$, and the maximum allowable limit is $139 \mathrm{dBA}$ with an exposure time not exceeding 0.11 seconds. Based on the regulation, noise in coal mines is a risk factor that must be controlled.

The impact exerted by noise on incidence with hypertension is classified as non-auditory impacts. Exposure to noise exacerbates a possibility of hypertension among coal mine workers. When exposed to noise, mine workers feel disturbed. These feelings lead to anxiety and stress among them. The stress causes cardiovascular changes in workers, one of which is an increase in blood pressure. Prolonged noise exposure will result in a necessity for a body to recover. This recovery includes elimination of non-auditory noise impacts. Stress caused by noise can become chronic. Chronic stress that causes an increase in blood pressure continues with the final manifestation of hypertension in coal mining workers.

Noise increases the risk of hypertension among workers in line with existing research. Previous research has shown that noise will have an impact on prolonged stress. This stress is then followed by an increase in blood lipids, blood viscosity, blood pressure, cardiac output, blood glucose, and blood clotting factors, which result in cardiovascular diseases, including stroke, ischemic heart disease, and arterial hypertension [26].

As for coal mine workers and their exposure to noise, the risk of hypertension can be reduced using personal protective equipment, especially those aimed at reducing noise expo- 
sure, both earplugs, and earmuffs when working under exposure to noise. Several earplugs and ear muffs in Indonesia can reduce noise received by workers by 10-20 dBA.

We also studied a relationship between hypertension among coal mine workers and exposure to dust. The high rate of hypertension in the study can also be caused by exposure to dust at a workplace. It has been explained previously that the environment at coal mines in Indonesia is dry, especially during hot or dry season, which results in dry soil conditions and causes much dust in summer or dry season. Dust that is a risk factor for coal mining workers comes from dry ground dust from coal being processed during mining activities.

Exposure to dust that enters through the respiratory tracts causes an increased risk of hypertension among coal mining workers due to dust being carried through the respiratory tracts and then to the lungs. The microscopic dust particles will continue to be carried around as blood circulation occurs from the lungs to the heart. The coarse particles then partially block blood flow to the heart. This inhibition of blood flow to the heart causes an increase in blood pressure, leading to hypertension in coal mining workers.

Experimental studies on humans related to dust also explain that humans exposed to dust particles with their diameter being 2.5-10 micrometers suffer from an increase in heart rate and systolic and diastolic blood pressure. This happens due to coarse particles carried by the bloodstream causing disruption of blood circu- lation to the heart $[27,28]$. Preventing increased risks of hypertension due to dust exposure can require workers to wear masks while working. A mask in question is a dust mask with the ability to filter dust up to particles with their diameter being 2.5 micrometers so that they cannot enter the respiratory tract. If coal mine workers use these masks, it is recommended to change cartridges in them periodically.

This discussion shows that examined coal mining environment creates an enormous risk of increased hypertension prevalence. A specific work system existing at Indonesian coal mines involves mining workers spending their nights in a cottage for several weeks, causing a possibility of even a higher risk of hypertension among them. This can possibly be due to work stress, a psychological burden of not meeting family, a poor diet, and exercise.

Conclusion. Based on the results of the study, we can conclude that there is a relationship between hypertension in parents' case history and incidence with hypertension among coal mining workers. This is sufficient to prove that heredity or genetics plays a role in increasing risks of hypertension among coal mining workers. Coal mining environment creates an enormous risk of increasing hypertension prevalence among coal mining workers.

Funding. The research was not granted any financial support.

Conflict of interests. The authors declare there is no any conflict of interests.

\section{References}

1. Nerenberg K.A., Zarnke K.B., Leung A.A., Dasgupta K., Butalia S., McBrien K., Harris K.C., Nakhla M. [et al.]. Hypertension Canada's 2018 Guidelines for Diagnosis, Risk Assessment, Prevention, and Treatment of Hypertension in Adults and Children. Can. J. Cardiol., 2018, vol. 34, no. 5, pp. 506-525. DOI: $10.1016 /$ j.cjca.2018.02.022

2. Pickering G. Hypertension. Definitions, natural histories and consequences. Am. J. Med., 1972, vol. 52, no. 5, pp. 570-583. DOI: 10.1016/0002-9343(72)90049-6

3. Kitaoka M., Mitoma J., Asakura H., Anyenda O.E., Nguyen T.T.T., Hamagishi T., Hori D., Suzuki F. [et al.]. The relationship between hypertension and health-related quality of life: adjusted by chronic pain, chronic diseases, and life habits in the general middle-aged population in Japan. Environ Health. Prev. Med., 2016, vol. 21, no. 4, pp. 193-214. DOI: 10.1007/s12199-016-0514-6

4. Hipertensi Penyakit Paling Banyak Diidap Masyarakat. Kementerian Kesehatan Republik Indonesia, 2018. Available at: https://www.kemkes.go.id/article/view/19051700002/hipertensi-penyakitpaling-banyak-diidap-masyarakat.html (03.08.2020). 
5. J. Sundström, H. Arima, R. Jackson, F. Turnbull, K. Rahimi, J. Chalmers, M. Woodward, B. Neal [et al.]. Effects of blood pressure reduction in mild hypertension: A systematic review and meta-analysis. Ann. Intern. Med., 2015, vol. 162, no. 3, pp. 184-191. DOI: 10.7326/M14-0773

6. Zhou D., Xi B., Zhao M., Wang L., Veeranki S.P. Uncontrolled hypertension increases risk of all-cause and cardiovascular disease mortality in US adults: The NHANES III Linked Mortality Study. Sci. Rep., 2018, vol. 20, no. 8 (1), pp. 9418. DOI: 10.1038/s41598-018-27377-2

7. Hipertensi. Pusat Data dan lnformasi Kementerian Kesehatan RI, 2018, 8 p.

8. Tambunan T. Recent evidence of the development of micro, small and medium enterprises in Indonesia. J. Glob. Entrep. Res., 2019, no. 9, pp. 18. DOI: 10.1186/s40497-018-0140-4

9. Shi X., Song Z. The Silent Majority: Local residents' environmental behavior and its influencing factors in coal mine area. J. Clean. Prod., 2019, no. 240, pp. 118275. DOI: 10.1016/j.jclepro.2019.118275

10. Bhattacherjee A., Kunar B. Miners' return to work following injuries in coal mines. Med. Pr., 2016, vol. 67, no. 6, pp. 729-742. DOI: 10.13075/mp.5893.00429

11. Ranasinghe P., Cooray D.N., Jayawardena R., Katulanda P. The influence of family history of Hypertension on disease prevalence and associated metabolic risk factors among Sri Lankan adults Chronic Disease epidemiology. BMC Public. Health, 2015, vol. 20, no. 15, pp. 576. DOI: 10.1186/s12889-015-1927-7

12. Frese E.M., Fick A., Sadowsky S.H. Blood Pressure Measurement Guidelines for Physical Therapists. Cardiopulm Phys. Ther. J., 2011, vol. 22, no. 2, pp. 5-12.

13. The Seventh Report of the Joint National Committee on Prevention, Detection, Evaluation, and Treatment of High Blood Pressure (JNC 7). U.S. department of health and human services; National Institutes of Health National Heart, Lung, and Blood Institute, 2003, pp. 104.

14. Chataut J., Khanal K., Manandhar K. Prevalence and associated factors of hypertension among adults in rural Nepal: A community based study. Kathmandu Univ. Med. J., 2016, vol. 13, no. 4, pp. 346-350. DOI: 10.3126/kumj.v13i4.16835

15. Egan B.M. Defining hypertension by blood pressure $130 / 80 \mathrm{~mm} \mathrm{Hg}$ leads to an impressive burden of hypertension in young and middle-aged black adults: Follow-up in the CARDIA study. J. Am. Heart. Assoc., 2018, vol. 17, no. 7 (14), pp. e009971. DOI: 10.1161/JAHA.118.009971

16. Buford T.W. Hypertension and aging. Ageing Res. Rev., 2016, vol. 26, no. 1, pp. 96-111. DOI: 10.1016/j.arr.2016.01.007

17. Lacerda J., Lopes M.R., Ferreira D.P., Fonseca F.L.A., Favaro P. Descriptive study of the prevalence of anemia, hypertension, diabetes and quality of life in a randomly selected population of elderly subjects from São Paulo. Rev. Bras. Hematol. Hemoter., 2016, vol. 38, no. 2, pp. 96-111. DOI: 10.1016/j.arr.2016.01.007

18. Liu M., He Y., Jiang B., Wang J., Wu L., Wang Y., Zhang D., Zeng J., Yao Y. Association between family history and hypertension among Chinese elderly. Med. (United States)., 2015, vol. 94, no. 48, pp. e2226. DOI: 10.1097/MD.0000000000002226

19. Yoo J.E., Park H.S. Relationship between parental hypertension and cardiometabolic risk factors in adolescents. J. Clin. Hypertens, 2017, vol. 19, no. 7, pp. 678-683. DOI: 10.1111/jch.12991

20. Chen H., Sun M., Fan Z., Wu X., Li J., Zhu Y., Zhu J. Fathers may play a bigger role than mothers in hypertensive patients complicated with coronary heart disease. Biomed Res., 2018, vol. 29, no. 3, pp. 558-562. DOI: 10.4066/biomedicalresearch.29-17-3230

21. Sun D., Liu J., Xiao L., Liu Y., Wang Z., Li C., Jin Y., Zhao Q., We S. Recent development of risk-prediction models for incident hypertension: An updated systematic review. PLoS One, 2017, vol. 12, no. 10, pp. e0187240. DOI: 10.1371/journal.pone.0187240

22. Ahn S.Y., Gupta C. Genetic programming of hypertension. Front Pediatr, 2018, vol. 22, no. 5, pp. 285. DOI: $10.3389 /$ fped.2017.00285

23. Suhu Minimum, Rata-Rata, dan Maksimum di Stasiun Pengamatan BMKG. Badan Pusat Statistik, 2017. Available at: https://www.bps.go.id/statictable/2017/02/09/1961/suhu-minimum-rata-ratadan-maksimum-di-stasiun-pengamatan-bmkg-oc-2011-2015.html (03.08.2020).

24. Swali A. The impact of heat stress on blood pressure. Heat Stress. Causes, Treatment and Prevention, 2012, no. 19, pp. 3809-3819.

25. Babich D.R., Bauer E.R., Vipperman J.R. Equipment Noise and Worker Exposure in the Coal Mining Industry. United States Natl Inst Occup Saf Heal (NIOSH), 2006, no. 2006, pp. 1-77. 
26. Münzel T., Sørensen M. Noise pollution and arterial hypertension. Eur. Cardiol. Rev., 2017, vol. 12, no. 1, pp. 26-29. DOI: 10.15420/ecr.2016:31:2

27. Byrd J.B., Morishita M., Bard R.L., Das R., Wang L., Sun Z., Spino C., Harkema J. [et al.]. Acute increase in blood pressure during inhalation of coarse particulate matter air pollution from an urban location. J. Am. Soc. Hypertens., 2016, vol. 10, no. 2, pp. 133-139. DOI: 10.1016/j.jash.2015.11.015

28. Pearson J.F., Bachireddy C., Shyamprasad S., Goldfine A.B., Brownstein J.S. Association between fine particulate matter and diabetes prevalence in the U.S. Diabetes Care. Diabetes Care, 2010, vol. 33, no. 10, pp. 2196-2201. DOI: 10.2337/dc10-0698

Kurnia Ardiansyah Akbar. Hypertension among coal mining workers associated with parental hypertension in Indonesia. Health Risk Analysis, 2021, no. 1, pp. 100-107. DOI: 10.21668/health.risk/2020.1.10.eng

Received: 19.08 .2020

Accepted: 03.03.2021

Published: 30.03 .2021 